\title{
A jobb pitvar echokardiográfiás vizsgálata - az M-módtól a 3D speckle-tracking képalkotásig
}

\author{
Nemes Attila dr. - Forster Tamás dr. \\ Szegedi Tudományegyetem, Általános Orvostudományi Kar, Szent-Györgyi Albert Klinikai Központ, \\ II. Belgyógyászati Klinika és Kardiológiai Központ, Szeged
}

\begin{abstract}
A jobb pitvar echokardiográfiás vizsgálata a jelen gyakorlatban nagy kihívás és csak korlátozott lehetőségek állnak rendelkezésünkre. Az utóbbi évtizedekben végbement technikai fejlesztések lehetővé teszik a komplex jobb pitvari szívciklusos mozgások volumetrikus és funkcionális analízisét. Ennek az összefoglaló közleménynek a célja a jelenleg elérhető rutineljárások mellett a legkorszerúbbnek tekinthető háromdimenziós és/vagy speckle-tracking echokardiográfiás módszerek bemutatása a jobb pitvar vizsgálatában. Orv. Hetil., 2016, 157(43), 1698-1707.
\end{abstract}

Kulcsszavak: jobb pitvar, funkció, echokardiográfia

\section{Echocardiographic evaluation of the right atrium - from M-mode to 3D speckle-tracking imaging}

Echocardiographic assessment of the right atrium is a great challenge in present practice and only limited opportunities are available. Technical improvements in the last decades enable volumetric and functional analysis of the complex right atrial cardiac cyclic movements. The aim of the present review is to demonstrate the most recent threedimensional and/or speckle tracking echocardiographic techniques over routine methodologies in the evaluation of the right atrium.

Keywords: right atrium, function, echocardiography

Nemes, A., Forster, T. [Echocardiographic evaluation of the right atrium - from M-mode to 3D speckle-tracking imaging]. Orv. Hetil., 2016, 157(43), 1698-1707.

(Beérkezett: 2016. június 15.; elfogadva: 2016. augusztus 11.)

\section{Rövidítések}

$2 \mathrm{D}=$ kétdimenziós; 2DE = kétdimenziós echokardiográfia; 2DSTE = kétdimenziós speckle-tracking echokardiográfia; 3D = háromdimenziós; 3DSTE = háromdimenziós speckle-tracking echokardiográfia; A = kései, a pitvari kontrakció idejére eső (A-hullám) JK-i diasztolés telődés sebessége (DE-vel mérve); $\mathrm{A}_{1}=\mathrm{JP}-\mathrm{i}$ area; $\mathrm{A}^{\prime}=$ tricuspidalis anulus előmozdulásának longitudinális sebessége késő diasztoléban (TDI-vel mérve); $\mathrm{AP} 4 \mathrm{CH}=($ apical 4 -chamber view $)$ apicalis 4 üregi nézet; $\mathrm{BK}=$ bal kamra; $\mathrm{BP}=$ bal pitvar; $\mathrm{DE}=$ Doppler-echokardiográfia; $\mathrm{E}=$ korai gyors JK-i diasztolés telődés sebessége (DE-vel mérve); E' = tricuspidalis anulus előmozdulásának longitudinális sebessége kora diasztoléban (TDI-vel mérve); EKG = elektrokardiográfia; $\mathrm{IVC}=$ inferior vena cava; $\mathrm{JK}=$ jobb kamra; $\mathrm{L}=$ JP-i hossztengelyi átmérő; MME = M-mód echokardiográfia; $\mathrm{RAEF}=$ (right atrial ejection force) jobb pitvari ejekciós erő; RT3DE = real-time háromdimenziós echokardiográfia; RV = (right ventricular) jobb kamrai; $S^{\prime}=$ tricuspidalis anulus elömozdulásának longitudinális sebessége szisztoléban (TDI-vel mérve); STE = speckle-tracking echokardiográfia; SVC = superior vena cava; TDI $=$ (tissue Doppler imaging) szöveti Doppler-echokardiográfia; V = JP-i térfogat; Vd = a hepaticus vénában Dopplerrel mért diasztolés hullám sebessége; Vs = a hepaticus vénában Dopplerrel mért szisztolés hullám sebessége 


\section{A jobb pitvar}

A jobb pitvar (JP) egy komplex struktúrájú szívüreg, amely a jobb kamrával (JK) a tricuspidalis vagy jobb atrioventricularis billentyứn keresztül közlekedik [1, 2]. A JP fontos része az anterior lokalizációjú JP-i fülcse és a crista terminalis, amely a JP anteromedialis falán ered, a superior vena cavával (SVC) szemben halad el az inferior vena cava (IVC) felé. A crista terminalisban a rostok lefutása párhuzamos annak lefutásával, ám azon túl az intercavalis régióban a rostok lefutása ferde. Az IVC szájadékát az Eustach-billentyü fedi le, amely néha nagy fenesztrált Chiari-hálózat képében mutatkozik. A sinus coronarius egy vénás csatorna, amely az atrioventricularis barázda mellett halad, és az IVC szájadéka és a tricuspidalis anulus között nyílik a JP-be. Fontos még megemlíteni az interatrialis septumot, amelyen a foramen ovale annak jobb oldalán helyezkedik el.

A bal pitvarhoz (BP-hez) hasonlóan a JP is dinamikus mozgást végez a szívciklusnak megfelelően, és feszülésének megfelelően pitvari natriureticus peptideket is elválaszt, és falában baroreceptorok is elhelyezkednek. A JP, a BP-hez hasonlóan, speciális mechanika szerint múködik: kamrai szisztolé idején az IVC, az SVC és a sinus coronarius felől érkező vér zárt tricuspidalis billentyü mellett feltölti a JP-t (a QRS-komplex, az izovolumetriás kontrakció, a kamrai szisztolé és az izovolumetriás relaxáció idejére esik). A tricuspidalis billentyü nyílásával kora diasztoléban a JK passzívan telődik aktív pitvari tevékenység nélkül („conduit” fázis), amit a diasztolé végén a pitvar aktív kontrakciója követ a P-hullámot követően („booster pump” funkció). A JP-i aktív kontrakció a JK-i verőtérfogat 15-30\%-árért felelős, pitvarfibrilláció fennállása esetén ez a fázis hiányzik [2].

Az echokardiográfia az egyik legszéleskörúbben alkalmazott egyszerú, relatíve könnyen megtanulható, sugárzással nem járó képalkotó eljárás. Sajnos kevés olyan módszertan létezik, amely a klinikumban alkalmazható a JP-i morfológia és funkció pontos meghatározására. A szakmai irányelvek szerint ezek a rutinban alkalmazott módszerek a JP-i méretek (átmérők, area, térfogat) 2D echokardiográfiás (2DE) mérésén alapulnak, míg a klinikai adatok figyelembevétele mellett becsülhetjük a JP-i nyomást is az IVC vizsgálatával (M-mód echokardiográfiával [MME] vagy 2DE-vel). Van lehetőségünk továbbá a JK diasztolés funkcióját (így indirekt módon a JP-i funkciót) is jellemezni Doppler- (DE) és szöveti Doppler-echokardiográfia (tissue doppler imaging - TDI) segítségével [3]. Amennyiben az így kapott paraméterek eltérést mutatnak (például nagyobb méretek, csökkent értékű funkcionális paraméterek), akkor a mögöttük álló folyamatok feltérképezése javasolt (például aritmia, congenitalis szívbetegség, jobb szívfelet érintő cardiomyopathia vagy valvularis eltérések stb. irányában) a klinikai tünettan és anamnesztikus adatok figyelembevétele mellett. Ilyenkor felmerülhet kardiológiai szakvizsgálat szükségessége is. Ezeket a klinikai gyakorlatban használatos módszertanokat az alábbiakban csillaggal jelöltük.

Köszönhetően azonban az utóbbi évtizedekben végbement technikai fejlesztéseknek, számos olyan új metodológia jelent meg (két- [2DSTE] és háromdimenziós speckle-tracking echokardiográfia [3DSTE] és real-time háromdimenziós echokardiográfia [RT3DE]), amelyek pontosabb és szélesebb körü lehetőséget tudnak nyújtani ennek a kevésbé ismert és vizsgált szívüregnek a vizsgálatában. Az általuk szolgáltatott paraméterek klinikai, diagnosztikus és prognosztikus értéke azonban nem kellően validált, így nem képezik a napi rutin részét. A jelen közlemény célja tehát kettős: bemutatni a klinikai gyakorlatban alkalmazható és a guideline-ok által ajánlott, de korlátozott lehetőségekkel bíró módszerek mellett a még fejlesztés alatt álló, de kecsegtető jövővel rendelkezô új eljárásokat is.

\section{M-mód echokardiográfia (MME)}

Az MME során a szív egy adott üregéról egy síkban az idő függvényében EKG-kapuzás mellett készítünk felvételt $[4]$.

\section{A jobb pitvar vizsgálata}

A klinikai rutinban az MME nem használatos a JP vizsgálatára [3].

\section{*Az inferior vena cava vizsgálata}

Az IVC vizsgálatára a subcostalis a leggyakrabban használt nézet. Az IVC átmérőjét a ráhelyezett $M$-mód segítségével a JP-be szájadzástól körülbelül 0,5-3 cm-re a hepaticus vénák beszájadzásától proximálisan a kilégzés végén mérjük $[3,5]$. Az IVC kollapszusát szippantásra és nyugodt belégzésre létrejövő IVC-átmérő-változásként értékeljük. JP-i nyomásemelkedés esetén az IVC belégzésre létrejövő csökkent kollapszusképessége és dilatációja figyelhető meg. Az ajánlás szerint a JP-i nyomás becslésére az alábbiak érvényesek [3]:

- Normális JP-i nyomás (3 Hgmm, 0-5 Hgmm) áll fenn, ha az IVC-átmérő $\leq 2,1 \mathrm{~cm}$ és a szippantásra a kollapszus $>50 \%$.

- Magas JP-i nyomás (15 Hgmm, 10-20 Hgmm) áll fenn, ha az IVC-átmérő $>2,1 \mathrm{~cm}$ és a szippantásra a kollapszus $<50 \%$.

- A köztes állapotokban a JP-i nyomás 8 Hgmm (5-10 Hgmm), ilyenkor szekunder jelek szükségesek az emelkedett JP-i nyomás igazolásához, mint a restriktív jobbszívfél-telődési minta, tricuspidalis $\mathrm{E} / \mathrm{E}^{\prime}>6$, diasztolés áramlási predominancia a hepaticus vénákban (szisztolés telődési frakció <55\%) (lásd később). Ha a köztes állapotokban ezek a szekunder jelek nem állnak fenn, akkor a JP-i nyomás 3 Hgmm-nek tekinthető. 
- Ha szippantásra minimális a kollapszus (<35\%) és a JP-i nyomásemelkedés szekunder jelei észlelhetók, akkor a JP-i nyomás 15 Hgmm lehet. Ha bizonytalanság áll fenn, akkor a JP-i nyomást a köztes állapotnak megfelelőnek tekintjük.

- Azokra a betegekre, akik nem tudnak szippantani, de nyugodt légzésre a kollapszus $<20 \%$, úgy tekintünk, hogy a JP-i nyomás emelkedett.

A fentieknek klinikai jelentősége van az arteria pulmonalis nyomásának megítélésében is [3].

\section{Kétdimenziós echokardiográfia (2DE)}

A 2DE a noninvazív rutin klinikai diagnosztikában az egyik leggyakrabban alkalmazott echokardiográfiás eljárás. $2 \mathrm{DE}$ során a szektorba illesztett szívüreget, jelen esetben a JP-t, egy adott síkban a szívciklusnak megfelelöen vizsgáljuk [4].

\section{*A jobb pitvar vizuális becslése}

Emelkedett JP-i nyomás esetén a JP kitágul és az interatrialis septum a BP-be domborulhat az egész szívciklus alatt [3]. Bár ezek csak kvalitatív jelek, fennállásuk esetén a JP-i nyomás mérésének egyéb lehetőségeire gondolni kell.

\section{*A jobb pitvari átmérốk mérése}

A JP-i átméróket az apicalis négyüregi (apicalis 4-chamber - AP4CH) nézetben mérjük oly módon, hogy megmérjük a maximális hossztengelyi átmérőt $(\mathrm{L})$ a tricuspidalis billentyű közepe és a superior JP-i fal közepe között (normálérték $<53 \mathrm{~mm}$ ) végszisztoléban. A JP hossztengelyének felénél mérjük annak keresztátmérőjét a JP-i szabad (anterolateralis) fal és az interatrialis septum között arra merőleges irányban (normálérték $<44 \mathrm{~mm}$ ) $[3,5,6]$ (1. ábra). A legújabb guideline szerint az L értéke férfiakban $2,4 \pm 0,3 \mathrm{~cm} / \mathrm{m}^{2}$, míg nókben $2,5 \pm 0,3 \mathrm{~cm} / \mathrm{m}^{2}$, ugyanezen értékek a keresztátméröre vonatkoztatva $1,9 \pm 0,3 \mathrm{~cm} / \mathrm{m}^{2}$ nemtől függetlenül [7].

\section{* A jobb pitvari areák mérése}

A JP-i areát $\left(\mathrm{A}_{1}\right)$ az átméróértékekhez hasonlóan AP4CH-nézetben mérjük planimetria segítségével, a szakmai vezérfonal szerint a kamrai szisztolé végén, amikor a pitvar a legnagyobb térfogatú [3] (1. ábra). A JP körberajzolása során a tricuspidalis billentyü anulusának lateralis és septalis szélét összekötjük, az SVC-t, az IVCt és a JP-i fülcsét kizárjuk a mérésből. Ennek megfelelően a planimetriával mért JP-i area normálértéke $<18 \mathrm{~cm}^{2}$. A JP-area megnagyobbodását észlelték bizonyos kórképekben (például atrialis septumdefektus fennállása esetén, állóképességi sportolókban stb.), míg a mortalitás és a transzplantáció prediktorának találták különböző álla- potokban (például primer pulmonalis hypertoniás betegekben, Eisenmenger-szindrómában stb.) [1, 3, 8]. Egy tanulmányban igazolták, hogy amennyiben a BP-i és JP-i areák aránya $>1$ ( „relative atrial index”) akut pulmonalis emboliás betegekben, az együtt jár a hosszú távú mortalitás háromszoros rizikójával [9].

\section{*A jobb pitvari térfogatok mérése}

Elvileg fennáll a lehetősége a BP-hez hasonlóan a JP-i térfogatértékek számításának is, azonban a jelenleg elérhető adatok limitáltak és kevés vizsgálati eredményen alapulnak $[3,7]$. Mivel a JP csak egy síkban ábrázolható $(\mathrm{AP} 4 \mathrm{CH})$, így a térfogatszámítások során az egysíkú area-length $\left\{\mathrm{V}=[8 /(3 \Pi)]\left(\mathrm{A}_{\mathrm{l}}{ }^{2} / \mathrm{L}\right)\right.$, ahol $\mathrm{V}$ a térfogat, $\mathrm{A}_{1}$ a JP-i area, míg az L a JP-i hossztengelyi átmérőt jelöli\} vagy „disk summation” módszert lehet használni [7] (1. ábra). Irodalmi adatok alapján a férfiak JP-i térfogata nagyobb, mint a nőké, és a JP-i térfogatok kisebbek, mint a BP-i [7]. Bár a 2010-es ajánlás még a JP-i térfogatméréseket nem ajánlotta [3], a 2015-ös guideline ajánlott paraméternek tekinti (normálérték férfiaknál $25 \pm 7 \mathrm{ml} / \mathrm{m}^{2}$, nók esetén $21 \pm 6 \mathrm{ml} / \mathrm{m}^{2}$ ) [7]

\section{*Az inferior vena cava vizsgálata}

Az MME-nél leírtak érvényesek [3].

\section{Doppler-echokardiográfia (DE)}

A DE a 2DE-hez hasonlóan a napi klinikai rutin része, segítségével egy mozgó szövetrészről visszaverődő hullám frekvenciájának (és hullámhosszának) megváltozását mérjük, amely arányos annak sebességével [4].

\section{*A tricuspidalis beáramlás jellemzése}

A bal szívfélhez hasonlóan a JP-i funkció meghatározható a pitvari ürülést jellemző, a tricuspidalis billentyűn keresztüli korai gyors (E-hullám) és kései, a pitvari kontrakció idejére eső (A-hullám) JK-i diasztolés telődéssel. Mérése pulzatilis Dopplerrel végezhető, normális esetben az E >A [3, 10] (2. ábra). A jobb szívfél esetén azonban mások a határértékek, mint a bal szívfélnél:

- enyhe, ha az $\mathrm{E} / \mathrm{A}<0,8$ (csökkent relaxáció, 1. típus);

- közepes, ha E/A 0,8-2,1 közé esik, valamint a TDIvel mért $\mathrm{E} / \mathrm{E}$ ' $>6$ vagy a hepaticus vénákban diasztolés áramlási predominancia van (pszeudonormális, 2. típus);

- súlyos, ha E/A >2,1 és az E-hullám decelerációs ideje $<120 \mathrm{~ms}$ (restriktív minta, 3. típus).

\section{A jobb pitvari ejekciós erô számitása}

Teoretikusan a kamrai késő diasztolé idejére eső JP-i szisztolés (kontraktilis) funkció jellemezhető a JP-i ejekciós 


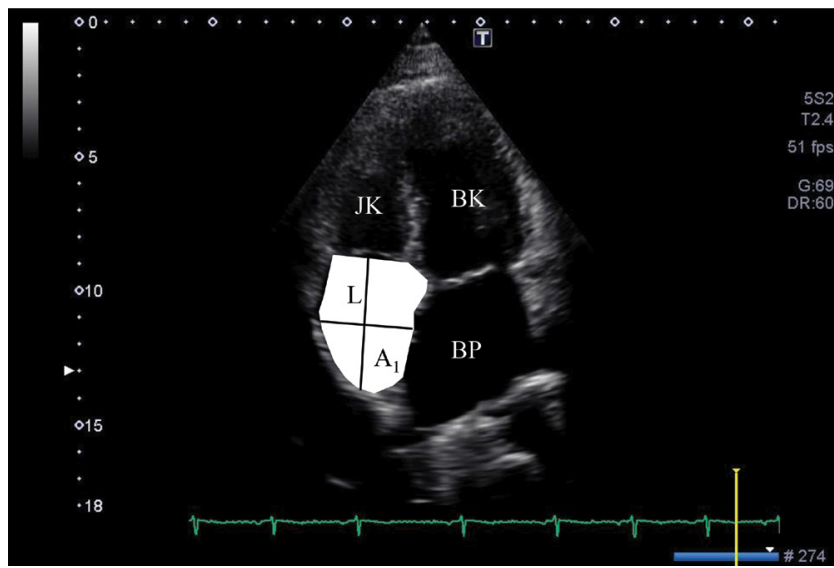

1. ábra

Kétdimenziós echokardiográfia során a jobb pitvari átmérőket és areát $\left(\mathrm{A}_{1}\right)$ csúcsi négyüregi $(\mathrm{AP} 4 \mathrm{CH})$ nézetben végszisztoléban mérjük (amikor a legnagyobb). A JP-i maximális hossztengelyi távolságot (átmérót) a tricuspidalis billentyú közepe és a superior JP-i fal közepe között mérjük, míg a JP hossztengelyének felénél mérjük annak keresztátmérőjét a JP-i szabad (anterolateralis) fal és az interatrialis septum között arra meróleges irányban

$\mathrm{BK}=$ bal kamra; $\mathrm{BP}=$ bal pitvar; $\mathrm{JK}=$ jobb karma; $\mathrm{JP}=$ jobb pitvar



2. ábra

Pulzatilis Doppler-echokardiográfia során a tricuspidalis billen tyú csúcsán mért transtricuspidalis diasztolés áramlást jellemző E- és A-hullámok mérhetôk

$\mathrm{BK}=$ bal kamra; $\mathrm{BP}=$ bal pitvar; $\mathrm{JK}=$ jobb kamra; $\mathrm{JP}=$ jobb pitvar
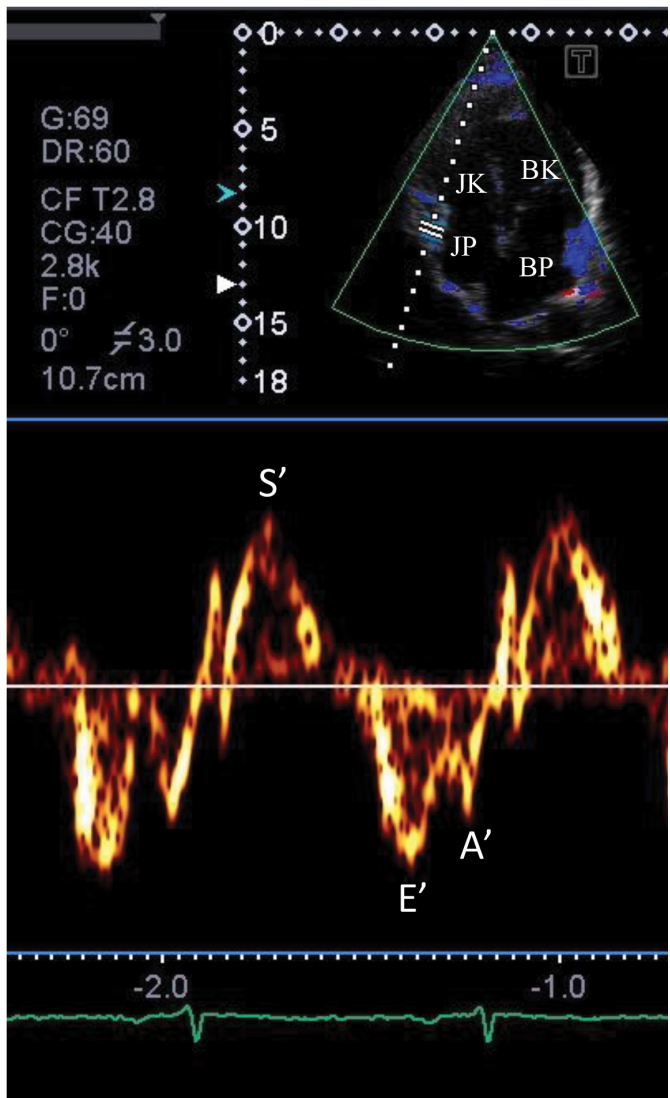

3. ábra

Szöveti Doppler-echokardiográfia segítségével a tricuspidalis anulus lateralis szélén rögzített típusos áramlási minta. A szisztolés longitudinális sebesség $\left(S^{\prime}\right)$ mellett korai (E') és késói (A') diasztolés myocardialis sebességértékeket tudunk mérni

$\mathrm{BK}=$ bal kamra; $\mathrm{BP}=$ bal pitvar; $\mathrm{JK}=$ jobb kamra; $\mathrm{JP}=$ jobb pitvar

erôvel (right atrial ejection force - RAEF), amely az alábbi képlettel számítható: $\mathrm{RAEF}=0,53 \times 1,06 \mathrm{~g} / \mathrm{cm}^{3} \times($ tricuspidalis diameter vagy orificium area) $\times$ transmitralis A-hullám sebessége, ahol az $1,06 \mathrm{~g} / \mathrm{cm}^{3}$ a vér denzitásértéke [11]. A módszer ismert, de alig használt.

\section{*Az inferior vena cava vizsgálata}

Az MME-nél leírtak érvényesek [3]. A csökkent JK-i tágulékonyság és emelkedett végdiasztolés nyomás a pitvari kontrakcióval reverz áramláshoz vezethet az IVC-ben (és a hepaticus vénákban), ami Dopplerrel detektálható [12].

\section{* A hepaticus vénák vizsgálata}

Alacsony vagy normális JP-i nyomás fennállása esetén szisztolés predominancia figyelhetô meg a hepaticus véna áramlásában, vagyis a szisztolés hullám sebessége (Vs) nagyobb, mint a diasztolés hullám sebessége (Vd) [3]. Emelkedett JP-i nyomás esetén a szisztolés predominancia elveszik, a Vs lényegesen csökken, a Vs $/ \mathrm{Vd}<1$. A hepaticus véna telődésifrakció-értékét az alábbi képlet- 
tel számíthatjuk: Vs/(Vs + Vd), ahol az 55\% feletti értéket találták az emelkedett JP-i nyomás szenzitív és specifikus jelének [13]. Bizonyos esetekben reverz áramlás is kimutatható [12].

\section{Szöveti Doppler-echokardiográfia (TDI)}

Az alacsony sebességű, de nagy amplitúdójú, hossztengelyi intrinszik anularis és myocardialis sebességértékek szöveti Doppler-echokardiográfia (tissue Doppler imaging - TDI) során noninvazív módon mérhetők [4].

\section{*A tricuspidalis anulus elmozdulási sebességértékeinek mérése}

A tricuspidalis lateralis anulusra helyezett TDI segítségével rögzített görbén hármas deflekció detektálható (3. ábra). A szisztolés longitudinális sebesség ( $S^{\prime}$ vagy $\mathrm{Sm}$ ) normálértéke $14,1 \pm 2,3 \mathrm{~cm} / \mathrm{s}$, a cutoff $<9,5 \mathrm{~cm} / \mathrm{s}$ pulzatilis TDI-vel mérve és $9,7 \pm 1,85 \mathrm{~cm} / \mathrm{s}$, a cutoff: $<6 \mathrm{~cm} / \mathrm{s}$ színes TDI-vel mérve [14]. Az S'-t radionuklid módszerrel meghatározott JK-i ejekciós frakcióval szemben validálták, a paraméter könnyen reprodukálható és prognosztikus ereje is igazolást nyert. Hátránya ismert szög- és töltésfüggésse, értékét a tricuspidalis regurgitatio befolyásolhatja $[12,14]$. A diasztolés funkciót korai (E') és késői (A') diasztolés myocardialis sebességértékekkel tudjuk jellemezni. Az emelkedett E/E' arány emelkedett JK-i töltőnyomást jelez. Abnormálisnak akkor tekinthető, ha E'<8 és az E/E'>6 [3, 10].

\section{Strain és strain rate képalkotás}

A TDI alkalmas egy adott szívüreg fali deformitásának kvantitatív jellemzésére a myocardium két szomszédos pontja sebességének és a két pont közötti relatív távolságnak a mérésével számítható strain rate (deformáció sebessége) és strainparaméterek segítségével [15]. Bár könnyen elérhető a technika, tekintettel a módszertannal együtt járó limitációkra (például szögfüggés, nagy „frame rate” szükséges a jó minőségü mérésekhez stb.), az STE ajánlott a strainparaméterek számítására (lásd később).

\section{Kétdimenziós speckle-tracking echokardiográfia (2DSTE)}

A speckle-tracking echokardiográfia (STE) során a szívizomszövetről visszaverődő természetes akusztikus markerek, az úgynevezett „speckle-k” detektálásának segítségével történik a képalkotás [2]. E szóródásos echoblokkok speciális mintázatainak térbeli (egy adott síkban) és időbeli (EKG-kapuzás melletti) továbbkövetésének a segítségével számíthatók volumetrikus és a fali deformációt jellemző paraméterek. 2DSTE során egysíkú mozgóképeken történnek a mérések speciális szoftve- rek segítségével. A módszer előnye, hogy nem töltés- és szögfüggő, és mind a volumetrikus, mind a deformációs paraméterek egyidejü mérésére alkalmas. Figyelembe kell azonban venni, hogy adott falrészletek mozgásai nem kétdimenziósak, így a síkból kilépő mozgások 2DSTE során nem ítélhetők meg korrekt módon (ezt a problémát a 3DSTE megoldja, lásd késóbb). A JP vizsgálata során speciális probléma, hogy fala vékonyabb a kamrákhoz képest, a szívüreg speciális alakja a méréseket nehézkessé teszi, szinte csak AP4CH (ritkábban subcostalis, csúcsi ötüregi) nézetben vizsgálható, és a JP-i fülcsét és a cavákat nem vesszük figyelembe az elemzések során [2].

\section{Volumetrikus adatok számitása}

2DSTE során AP4CH-nézetben szívciklus szerinti időtérfogat változás görbét tudunk létrehozni, amelyen a szisztolés legnagyobb $\left(\mathrm{V}_{\max }\right)$, a kora diasztolés, a pitvari szisztolé előtti („pre-atrial contraction”, EKG-n a P-hullám idején mért $\mathrm{V}_{\text {preA }}$ ) és a késő diasztolés legkisebb $\left(\mathrm{V}_{\text {min }}\right)$ JP-i térfogatértékek lemérhetők (4. ábra). Ezeknek az adatoknak a felhasználásával térfogatérték-alapú, a JP-i funkciókat figyelembe vevő funkcionális verőtérfogat (stroke volume) és ürülési frakció (emptying fraction) paraméterek számíthatók [16] (2. ábra):

Rezervoár funkció:

- Total atrial stroke volume (TASV) $=\mathrm{V}_{\max }-\mathrm{V}_{\min }$.

- Total atrial emptying fraction $($ TAEF $)=$

$\mathrm{TASV} / \mathrm{V}_{\max } \times 100$.

„Conduit” funkció:

- Passive atrial stroke volume $(\mathrm{PASV})=\mathrm{V}_{\max }-\mathrm{V}_{\text {preA }}$.

- Passive atrial emptying fraction $(\mathrm{PAEF})=$

$\left(\mathrm{V}_{\text {max }}-\mathrm{V}_{\text {preA }}\right) / \mathrm{V}_{\max } \times 100$.

Aktív kontrakció:

- Active atrial stroke volume $(\mathrm{AASV})=\mathrm{V}_{\text {preA }}-\mathrm{V}_{\min }$.

- Active atrial emptying fraction $(\mathrm{AAEF})=$

$\mathrm{AASV} / \mathrm{V}_{\text {preA }} \times 100$.

A fentieken túl a térfogatértékekből számos egyéb paraméter is számítható, azonban JP-re vonatkoztatva ezekkel kapcsolatban kevés az elérhető információ [17].

\section{Strainparaméterek számítása}

A volumetrikus adatok mérésén túl AP4CH-nézetben rögzített mozgófelvételen egyidejüleg longitudinális idő-strain és idő-strain rate (vagy akár idő-elmozdulás és idő-sebesség) görbék is rögzíthetők, amelyeket a 4 . ábrán szemléltetünk. Teoretikusan JP-i transversalis strain mérésének lehetősége is fennáll, de ennek nincs irodalma. Globális (az egész pitvarra vonatkozó) és szegmentális paraméterek számíthatók, utóbbiakból átlagolt értékek mérhetők. Fennáll a lehetősége, hogy külön-külön paramétereket számítsunk egy adott falrészlet közepére vagy belső-külső felületére. A számított strain és strain rate értékek segítségével valamennyi pitvari funkció (szisztolés rezervoár, kora diasztolés „conduit” és 


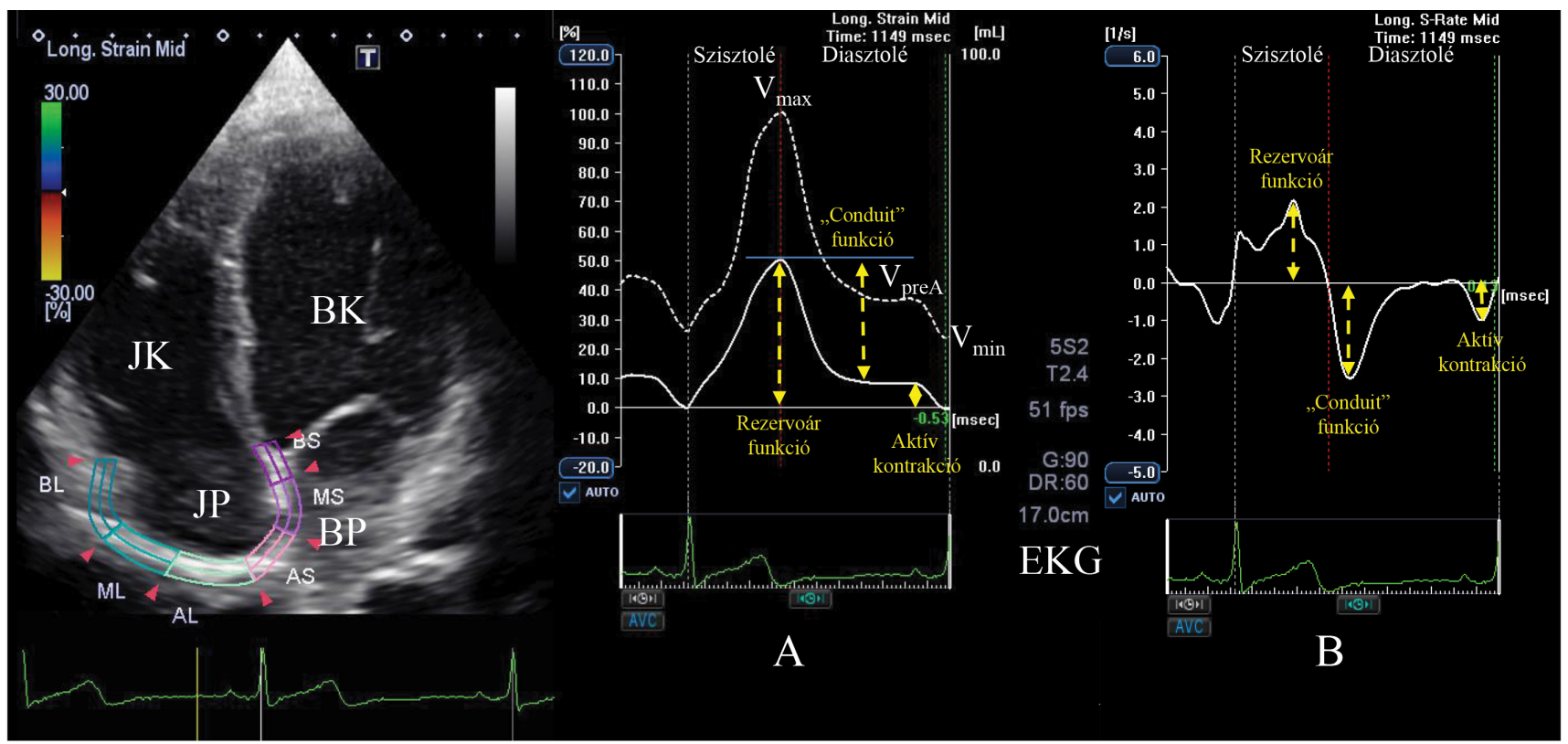

4. ábra

Kétdimenziós speckle-tracking echokardiográfia során a kétdimenziós apicalis 4 üregi felvételen a globális longitudinális strain (folyamatos fehér vonal) (A) és strain rate (B), valamint a szívciklus szerinti üregi térfogatváltozás (szaggatott fehér vonal) (A) egyidejúleg vizsgálható. A szívciklusnak megfelelően a szisztolés rezervoár, a kora diasztolés „conduit” és a késő diasztolés aktív kontrakció idején mérhető strain (A) és strain rate (B) paraméterek az ábra szerint mérhetők, a maximális $\left(\mathrm{V}_{\max }\right)$, a pitvari kontrakciót megelőző $\left(\mathrm{V}_{\text {preA }}\right)$ és minimális $\left(\mathrm{V}_{\min }\right)$ térfogatértékek egyidejűleg számíthatóak (A)

$\mathrm{BK}=$ bal kamra; $\mathrm{BP}=$ bal pitvar; $\mathrm{EKG}=$ elektrokardiográfia; $\mathrm{JK}=$ jobb kamra; JP = jobb pitvar
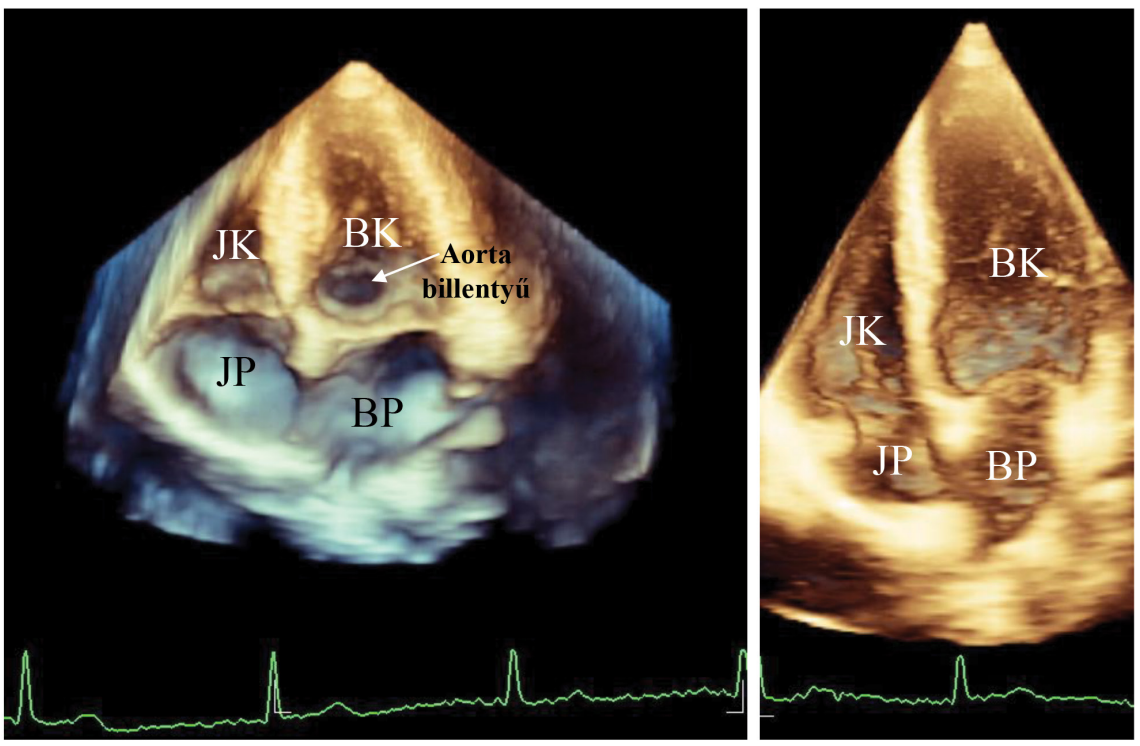

Végdiasztolé

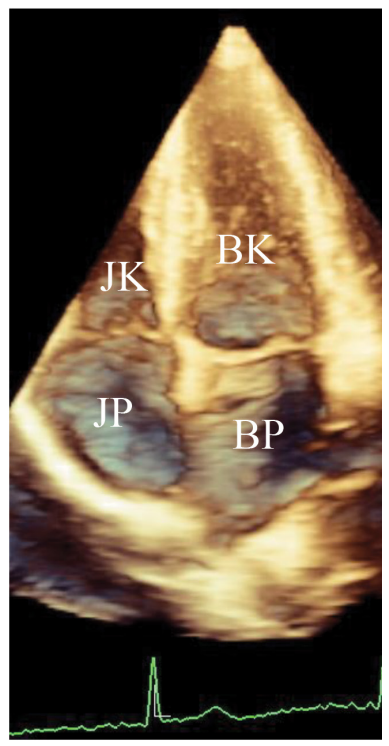

Végszisztolé

5. ábra $\mid$ Volumetrikus real-time háromdimenziós echokardiográfia során a digitálisan begyújtött echoködöt speciális szoftverek segítségével tudjuk elemezni, a szív és azok üregei térben vizsgálhatók

$\mathrm{BK}=$ bal kamra; $\mathrm{BP}=$ bal pitvar; $\mathrm{JK}=$ jobb kamra; $\mathrm{JP}=$ jobb pitvar

késő diasztolés aktív kontrakció) jellemezhető a 4. ábrán feltüntetett módon $[1,2]$. Több tanulmányban is ismertették a 2DSTE-vel mérhető strain és strain rate paraméterek normálértékét egészséges populációban [18, 19]. Egy tanulmány szerint a csúcs globális strain és strain rate elöre jelezheti a pulmonalis hypertoniát szívelégtelen betegekben [20]. Egy másik munkacsoport a lateralis fal JP-i strainjét csökkentnek találta olyan dilatatív cardiomyopathiás betegekben, akik nonreszponderek voltak a reszponderekhez képest [21]. A pitvari kontrakció idején mért longitudinális JP-i strain és strain rate értékét csökkentnek találták koszorúérbetegekben, amit a JK-i verőtérfogat fenntartásához szükséges kompenzáló mechanizmusként értékeltek [22]. 


\section{Real-time háromdimenziós echokardiográfia (RT3DE)}

A real-time háromdimenziós (3D) echokardiográfia (RT3DE) egy fiatal, de rövid idő alatt hatalmas karriert befutott, „forradalminak” leírt echokardiográfiás eljárás. Nemzetközileg 2003-ban lett bemutatva [23]. RT3DE során egy speciális szívultrahang-készülék és úgynevezett mátrixtranszducer használata mellett a szívről (vagy annak egy üregére fókuszálva, például a JP-ról) 3D echoködöt („3D volume-ot”, 3D adatbázist) gyújtünk be digitálisan EKG-kapuzás mellett. Ennek a piramis alakú térbeli adatbázisnak a felhasználásával speciális szoftverek segítségével térbeli képek készíthetők (5. ábra), illetve fél- vagy teljesen automatikus szövet-vér határfelismerő programok segítségével bármely szívüregrốl, így a JP-ról is 3D modell hozható létre.

\section{Volumetrikus adatok számitása}

RT3DE során a JP-rôl készített modell segítségével a szívciklust is figyelembe vevő térfogatértékek és azok változása mérhetô. A vizsgálatok EKG-kapuzás mellett történnek, így a digitálisan rögzített képsorozatokból a szisztolés $V_{\max }$ és diasztolés $V_{\text {preA }}$ és $V_{\text {min }}$ könnyen lemérhető, és a 2DSTE-nél bemutatott, a JP-i funkciókat figyelembe vevő térfogatalapú paraméterek számíthatók. Egy közelmúltban megjelent tanulmány szerint az RT3DE-vel mért JP-i térfogatok jól korrelálnak a mágneses rezonanciás vizsgálat során mért értékekkel, de az egyes betegek értékeiben az egyetértés mindössze közepes fokúnak bizonyult [24]. Egy másik tanulmányban az RT3DE-t a komputertomográfhoz hasonlították a JP-i térfogatértékek mérésében, és a két módszer között jó korreláció volt igazolható, bár az RT3DE lényegesen

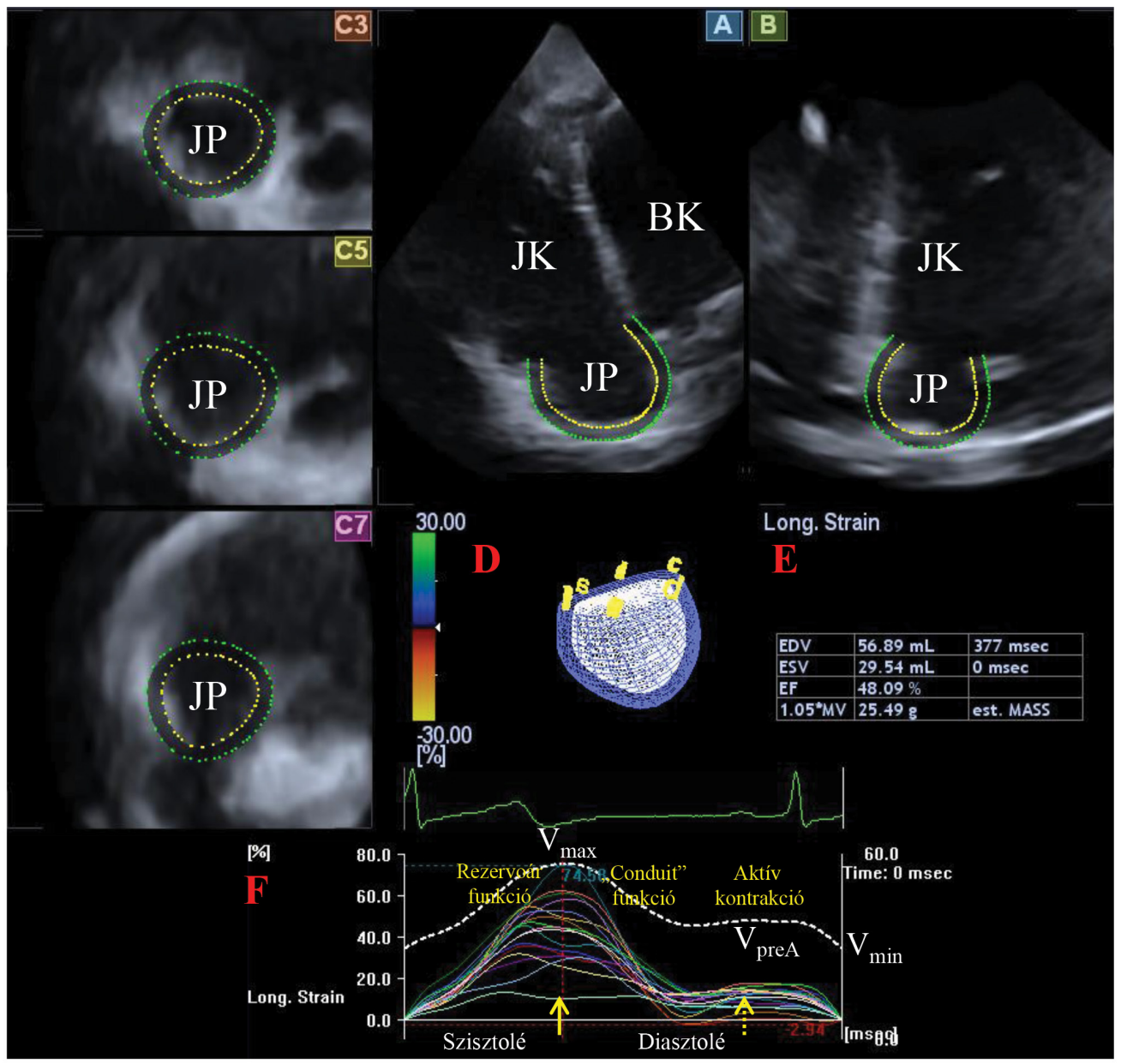

6. ábra

Háromdimenziós (3D) speckle-tracking echokardiográfia a digitálisan rögzített 3D echoköd felhasználásával 3D modell hozható létre a jobb pitvarról. A 3D adatbázisból a szoftver automatikusan kétdimenziós apicalis 4 üregi (A) és 2 üregi (B), valamint a jobb pitvar különböző szintjein keresztmetszeti nézetet $(\mathrm{C} 3, \mathrm{C} 5, \mathrm{C} 7)$ készít. A jobb pitvarról 3D modell (piros D) is készíthető, amelynek felhasználásával számos volumetrikus adat számítható (piros E). A fentieken túl a szívciklust is figyelembe vevő globális térfogatváltozás (fehér szaggatott vonal) és számos globális és szegmentális funkcionális paraméter („displacement”, rotáció, strain stb.) számítható (jelen esetben longitudinális strain) (piros F). Az EKG-jel segítségével tudunk eligazodni a szívciklusban, a készülék a rezervoár funkciót jellemző csúcsstraint (sárga nyíl) és a pitvari aktív kontrakció idején mért straint (szaggatott sárga nyíl) automatikusan kiszámítja

$\mathrm{BK}=$ bal kamra; $\mathrm{JK}=$ jobb kamra; $\mathrm{JP}=$ jobb pitvar; $\mathrm{V}_{\max }=$ szisztolé idején mért maximális JP-i térfogat; $\mathrm{V}_{\min }=$ diasztolé végén mért minimális JP-i térfogat; $\mathrm{V}_{\text {preA }}=$ a pitvari kontrakciót megelőző (a P-hullám idején mért „pre-atrial contraction”) JP-i térfogat 
alulmért [25]. Egy RT3DE-tanulmányban igazolást nyert, hogy a BK-i geometria hatással van a JP-i funkcióra [26], míg egy nagyobb esetszámú egészséges populációban végzett tanulmányban bemutatták a JP-i térfogatok RT3DE-vel mért normálértékeit [19].

\section{A jobb pitvari ejekciós erō számitása}

Teoretikusan a bal pitvari ejekciós erő analógiájára a késó diasztolés jobb pitvari aktív kontrakció jellemzésére a RAEF akár RT3DE-vel is kiszámítható [11, 27, 28]. A tricuspidalis billentyư anulusának „en-face" (szemből) ábrázolását követően annak méretei (átmérő, area) pontosan lemérhetők, majd a korábban megadott képlet segítségével a RAEF számítható [28]. Ezzel kapcsolatos irodalom azonban egyelőre nem elérhető.

\section{Háromdimenziós speckle-tracking echokardiográfia (3DSTE)}

A háromdimenziós speckle-tracking echokardiográfia (3DSTE) a legújabb echokardiográfiás fejlesztés, amely lehetővé teszi a JP teljes körú morfológiai és funkcionális vizsgálatát [29]. A módszertan egyesíti a 3D echokardiográfia és az STE előnyeit: a virtuálisan létrehozott 3D modell segítségével a JP-i méretek mellett egyidejüleg annak funkciója is széleskörüen elemezhető (6. ábra). 3DSTE során speciális készülék és úgynevezett mátrixtranszducer használata és EKG-kapuzás mellett az RT3DE-hez hasonlóan digitálisan 3D echoködöt rögzítünk, majd speciális szoftverek segítségével online vagy offline 3D modellt hozunk létre az adott szívüregről. A módszertan lényege, hogy a digitálisan rögzített 3D adatbázisban a myocardium „speckle”-jeinek (echomintázatainak) felismerését követően azok 3D térbeli és a szívciklusnak megfelelő időbeli követése történik, amely a térfogatméréseken túl a falmozgások (a fali „deformitás”) kvantitatív jellemzésére ad lehetőséget. A módszertan nagyon fiatal [29], a validációs tanulmányok többsége a BK-ra/BP-re vonatkozik [30-32]. A JP-vel kapcsolatos vizsgálatok száma minimális és nem kellően validált [33-35].

\section{Volumetrikus adatok számitása}

A 3DSTE a szívüregi térfogatok mérésében a BK-ra és a BP-re validált módszer annak ellenére, hogy speciálisan a pitvarra kifejlesztett alkalmazás jelenleg nem elérhető opció [30-32]. A JP-i térfogatok szívciklus szerinti méréséhez a BK-i modellt kell alkalmazni, hasonlóan a BP-n végzett vizsgálatokhoz. A JP-i 3D modellalkotás során az üregi térfogatváltozások jól követhetők, a $\mathrm{V}_{\text {max }}, \mathrm{V}_{\text {preA }}$ és a $\mathrm{V}_{\min }$ könnyen kiszámítható, ahogy azt a 6 . ábra is szemlélteti. A módszertan pontossága a JP-i térfogatmérésekben eddig nem igazolt. Az elérhető közlemények összefüggéseket igazoltak a JP-i térfogatok és BK funk- ciója között egészségesekben [33], illetve emelkedett JP-i térfogatértékeket találtak izolált BK-i nem kompaktálódás esetén [34] és korrigált Fallot-tetralógiában [35].

\section{Strainparaméterek számitása}

A BK/BP-hez hasonlóan 3DSTE segítségével a falmozgások és a fali deformáció kvantitatív jellemzésére alkalmas strainparaméterek számíthatók a térfogatmérésekkel egy időben ugyanazt a JP-i 3D modellt felhasználva. A szoftver használata közben a felhasználó választhatja ki, mely globális, átlagolt szegmentális és szegmentális uni- (radiális, longitudinális, circumferentialis) és multidirekcionális (area, 3D) strainparaméterre kíváncsi. Tekintettel a komplex pitvari mozgásokra, a 2DSTE-hez hasonlóan strainértékekkel jellemezhető a szisztolés rezervoár, a kora diasztolés „conduit” és a késő diasztolés aktív kontrakció (6. ábra). A fentieken túl „displacement" (elmozdulás), rotációs, csavarodási ('twist') stb. paraméterek is számíthatók, amelyek klinikai jelentősége azonban a JP esetén nem ismert, kutatás tárgya. A jelenleg elérhető vizsgálatok lényeges eltéréseket igazoltak mind a rezervoár funkciót jellemző csúcs, mind a pitvari kontrakció idején mért JP-i strainek értékében korrigált Fallot-tetralógiában [35]. Egy másik tanulmányban azonban csak enyhe JP-i funkcionális eltérések voltak igazolhatók izolált BK-i nem kompaktálódás esetén [34]. Egy további tanulmányban összefüggéseket találtak a JP-i deformáció és a 2DE-vel jellemzett BK-i paraméterek között már egészségesekben [33].

\section{A jobb pitvari ejekciós erố számitása}

Teoretikusan az RT3DE-hez hasonlóan 3DSTE segítségével is számítható RAEF, de ezzel kapcsolatos irodalom nem elérhető.

\section{Következtetések}

A jelen összefoglaló közlemény célja a JP vizsgálatára alkalmas transthoracalis echokardiográfiás módszerek bemutatása volt, a transoesophagealis és kontrasztanyagos echokardiográfiás eljárások bemutatásától eltekintettünk. Sajnos a napjainkban alkalmazott módszerek limitált lehetőséget nyújtanak a JP vizsgálatára, ezért a szakirodalomban csak „elfelejtett, mellőzött” szívüregnek szokták nevezni $[1,2]$. Köszönhetően az elmúlt évtizedekben véghezvitt technikai fejlesztéseknek, ma már elérhető lehetőség a JP-ről digitálisan virtuális, a szívciklust is figyelembe vevő 3D modell készítése, volumetrikus mérések végzése és/vagy a falmozgások kvantitatív jellemzése STE során. A korszerúbb metodológiák esetén az adatok limitáltsága miatt normálértékeket nem adtunk meg. Remélhetően ezek a módszertanok idővel be fognak szivárogni a klinikai kardiológiába, és az általuk 
szolgáltatott paraméterek diagnosztikus és prognosztikus jelentősége is igazolást fog nyerni. Ennek jelentősége nem kérdéses, hiszen minél több klinikai információra lenne szükségünk errôl a kevésbé ismert, és talán sok titkot rejtő szívüregről.

Anyagi támogatás: A közlemény megírása anyagi támogatásban nem részesült.

Szerzői munkamegosztás: N. A., F. T.: A kézirat megszövegezése, irodalmazás. A cikk végleges változatát mindkét szerző elolvasta és jóváhagyta.

Érdekeltségek: A szerzőknek nincsenek érdekeltségeik.

\section{Irodalom}

[1] Tadic, M.: The right atrium, a forgotten cardiac chamber: an updated review of multimodality imaging. J. Clin. Ultrasound, 2015, 43(6), 335-345.

[2] Rai, A. B., Lima, E., Munir, F., et al.: Speckle tracking echocardiography of the right atrium: the neglected chamber. Clin. Cardiol., 2015, 38(11), 692-697.

[3] Rudski, L. G., Lai, W. W., Afilalo, J., et al.: Guidelines for the echocardiographic assessment of the right heart in adults: a report from the American Society of Echocardiography endorsed by the European Association of Echocardiography, a registered branch of the European Society of Cardiology, and the Canadian Society of Echocardiography. J. Am. Soc. Echocardiogr., 2010, 23(7), 685-713.

[4] Nemes, A., Forster, T.: Echocardiographic assessment of the right ventricular morphology and function - from M-mode to $3 \mathrm{D}$ speckle-tracking imaging. [A jobb kamrai morfológia és funkció echokardiográfiás vizsgálata - az M-módtól a 3D speckle-tracking képalkotásig.] Cardiol. Hung., 2016, 46(3), 171-183. [Hungarian]

[5] Moreno, F. L., Hagan, A. D., Holmen, J. R., et al.: Evaluation of size and dynamics of the inferior vena cava as an index of rightsided cardiac function. Am. J. Cardiol., 1984, 53(4), 579-585.

[6] Bommer, W., Weinert, L., Neumann, A., et al.: Determination of right atrial and right ventricular size by two-dimensional echocardiography. Circulation, 1979, 60(1), 91-100.

[7] Lang, R. M., Badano, L. P., Mor-Avi, V., et al.: Recommendations for cardiac chamber quantification by echocardiography in adults: an update from the American Society of Echocardiography and the European Association of Cardiovascular Imaging. Eur. Heart J. Cardiovasc. Imaging, 2015, 16(3), 233-271.

[8] Fontana, G. P., Kirkman, J. H., DiSessa, T. G., et al.: Evaluation of right ventricular and right atrial size in children with atrial septum defect using two-dimensional apex echocardiography. J. Clin. Ultrasound, 1982, 10(8), 385-390

[9] Chow, V., Ng, A. C., Chung, T., et al.: Right atrial to left atrial area ratio on early echocardiography predicts long-term survival after acute pulmonary embolism. Cardiovasc. Ultrasound, 2013, $11,17$.

[10] Kossaify, A.: Echocardiographic assessment of the right ventricle, from the conventional approach to speckle tracking and threedimensional imaging, and insights into the "right way" to explore the forgetten chamber. Clin. Med. Insights Cardiol., 2015, 9, 65-75

[11] Manning, W. J., Silverman, D. I., Katz, S. E., et al.: Atrial ejection force: a noninvasive assessment of atrial systolic function. J. Am. Coll. Cardiol., 1993, 22(1), 221-225.
[12] DiLorenzo, M. P., Bhatt, S. M., Mercer-Rosa, L.: How to best assess right ventricular function by echocardiography. Cardiol. Young, 2015, 25(8), 1473-1481.

[13] Nagueh, S. F., Kopelen, H. A., Zoghbi, W. A.: Relation of mean right atrial pressure to echocardiographic and Doppler parameters of right atrial and right ventricular function. Circulation, 1996, 93(6), 1160-1169.

[14] Surkova, E., Muraru, D., Iliceto, S., et al.: The use of multimodality cardiovascular imaging to assess right ventricular size and function. Int. J. Cardiol., 2016, 214, 54-69.

[15] Opdabl, A., Helle-Valle, T., Skulstad, H., et al.: Strain, strain rate, torsion, and twist: echocardiographic evaluation. Curr. Cardiol. Rep., 2015, 17(3), 568.

[16] Anwar, A. M., Soliman, O. I., Geleijnse, M. L., et al.: Assessment of left atrial volume and function by real-time three-dimensional echocardiography. Int. J. Cardiol., 2008, 123(2), 155-161.

[17] Hoit, B. D.: Left atrial size and function: role in prognosis. J. Am. Coll. Cardiol., 2014, 63(6), 493-505.

[18] Padeletti, M., Cameli, M., Lisi, M., et al.: Reference values of right atrial longitudinal strain imaging by two-dimensional speckle tracking. Echocardiography, 2012, 29(2), 147-152.

[19] Peluso, D., Badano, L. P., Muraru, D., et al.: Right atrial size and function assessed with three-dimensional and speckle-tracking echocardiography in 200 healthy volunteers. Eur. Heart J. Cardiovasc. Imaging, 2013, 14(11), 1106-1114.

[20] Padeletti, M., Cameli, M., Lisi, M., et al.: Right atrial speckle tracking analysis as a novel noninvasive method for pulmonary hemodynamics assessment in patients with chronic systolic heart failure. Echocardiography, 2011, 28(6), 658-664.

[21] D'Andrea, A., Scarafile, R., Riegler, L., et al.: Right atrial size and deformation in patients with dilated cardiomyopathy undergoing cardiac resynchronization therapy. Eur. J. Heart Fail., 2009, 11(12), 1169-1177.

[22] Yan, P., Sun, B., Shi, H., et al.: Left atrial and right atrial deformation in patients with coronary artery disease: a velocity vector imaging-based study. PloS ONE, 2012, 7(12), e51204.

[23] Franke, A., Kühl, H. P.: Second-generation real-time 3D echocardiography: a revolutionary new technology. Medica Mundi, $2003,47(2), 34-40$.

[24] Müller, H., Carballo, D., Dos Santos, S., et al.: Measurement of right atrial volumes: comparison of a semi-automatic algorhytm of real-time 3D echocardiography with cardiac magnetic resonance imaging. Int. J. Cardiol., 2016, 202, 621-623.

[25] Takahashi, A., Funabashi, N., Kataoka, A., et al.: Quantitative evaluation of right atrial volume and right atrial emptying fraction by 320 -slice computed tomography compared with threedimensional echocardiography. Int. J. Cardiol., 2011, 146(1), 96-99.

[26] Tadic, M., Cuspidi, C., Kocijancic, V., et al.: Does left ventricular geometric patterns impact right atrial phasic function? Findings from the hypertensive population. Echocardiography, 2016, 33(8), 1186-1194.

[27] Chinali, M., de Simone, G., Roman, M. J., et al.: Left atrial systolic force and cardiovascular outcome: The Strong Heart Study. Am. J. Hypertens., 2005, 18(12 Pt 1), 1570-1576.

[28] Piros, G. Á., Domsik, P., Kalapos, A., et al.: Left atrial ejection force correlates with left atrial strain and volume-based functional properties as assessed by three-dimensional speckle tracking echocardiography (from the MAGYAR-Healthy Study). Rev. Port. Cardiol., 2016, 35(2), 83-91.

[29] Seo, Y., Ishizu, T., Atsumi, A., et al.: Three-dimensional speckle tracking echocardiography. Circ. J., 2014, 78(6), 1290-1301.

[30] Nesser, H. J., Mor-Avi, V., Gorissen, W., et al.: Quantification of left ventricular volumes using three-dimensional echocardiographic speckle tracking: comparison with MRI. Eur. Heart J., 2009, 30(13), 1565-1573.

[31] Kleijn, S. A., Aly, M. F., Terwee, C. B., et al.: Comparison between direct volumetric and speckle tracking methodologies for 
left ventricular and left atrial chamber quantification by threedimensional echocardiography. Am. J. Cardiol., 2011, 108(7), 1038-1044.

[32] Nemes, A., Domsik, P., Kalapos, A., et al.: Comparison of threedimensional speckle-tracking echocardiography and two-dimensional echocardiography for evaluation of left atrial size and function in healthy volunteers (Results from the MAGYAR-Healthy Study). Echocardiography, 2014, 31(7), 865-871.

[33] Piros, G. Á., Domsik, P., Kalapos, A., et al.: Relationships between right atrial and left ventricular size and function in healthy subjects. Results from the three-dimensional speckle-tracking echocardiographic MAGYAR-Healthy Study. [A jobb pitvar és bal kamra méretének és funkciójának összefüggései egészségesekben. Eredmények a háromdimenziós speckle-tracking echokardiográfiás MAGYAR-Healthy Tanulmányból.] Orv. Hetil., 2015, 156(24), 972-978. [Hungarian]
[34] Nemes, A., Domsik, P., Kalapos, A., et al.: Right atrial deformation analysis in isolated left ventricular noncompaction - Insights from the three-dimensional speckle tracking echocardiographic MAGYAR-Path Study. Rev. Port. Cardiol., 2016, 35(10), 515521.

[35] Nemes, A., Havasi, K., Domsik, P., et al.: Evaluation of right atrial dysfunction in patients with corrected tetralogy of Fallot using 3D speckle-tracking echocardiography. Insights from the CSONGRAD Registry and MAGYAR-Path Study. Herz, 2015, 40(7), 980-988.

(Nemes Attila dr., Szeged, Semmelweis u. 8., 6725 e-mail: nemes.attila@med.u-szeged.hu)

\section{PÁLYÁZAT}

A Prof. Dr. Romics László Akadémikus Emlékére Alapítvány pályázatot hirdet Magyarországon dolgozó, magyar állampolgárságú, 40 éven aluli orvosok és orvosbiológiai kutatással foglalkozó személyek számára. A nyertes pályázó(k) között 500000 Ft alapítványi adomány kerül kiosztásra.

A pályázat célja: a klinikai gyógyítás vagy orvosi tudományos kutatás területén dolgozók kiemelkedő tudományos tevékenységének elismerése.

Előnyt élveznek azok a pályázók, akik az alapítvány névadójának munkásságát folytatva cardiovascularis és anyagcsere-betegségek területéről nyújtanak be pályázatot.

A pályázatot természetes személy, saját nevében, magyar nyelven nyújthatja be, a pályázati anyag ábrák nélkül maximum 15000 leütés (karakter) terjedelmü lehet. A pályázathoz mellékelni kell egy rövid szakmai életrajzot.

A pályázat benyújtásának határideje: 2017. január 31. (elbírálásának határideje: 2017. április 30.)

A pályázatot a palyazat@romicsalapitvany.hu e-mail címre pdf formátumban kell benyújtani.

A pályázat benyújtását saját kézzel aláírt és dátummal ellátott levélben kell bejelenteni az alapítvány titkárának címezve (a borítékra írandó cím: dr. Dudás Márta, 1461 Budapest, Pf 62.) könyvelt (ajánlott) küldeményben, mert ezen bejelentés alapján válik hitelessé a pályázat.

Az alapítvány adatairól, müködéséről a www.romicsalapitvany.hu honlapon található információ. 